\title{
The Influence of Maternal Acceptance-Rejection and Adolescents Self Esteem to Bullying Behavior Junior High School Students
}

\author{
Siti Aviani Nur Azizah*1), Dwi Hastuti ${ }^{2}$ \\ ${ }^{1,2}$ Department of Family and Consumer Sciences, Faculty of Human Ecology, IPB \\ University, Bogor 16680, Indonesia \\ Corresponding author: sitiavianinurazizah@gmail.com
}

\begin{abstract}
This study aimed to analyze the influence of maternal acceptance-rejection and selfesteem adolescents on bullying behavior of junior high school students. The study took place at two junior high schools located in Bogor City and involved 86 students who were selected using simple random sampling. The measuring instrument used in this study was a PAR adaptation from Rohner (1986) with a reliability of 0.785 , self-esteem instrument adaptation from Rosenberg's (1965) with a reliability of 0.773 , and a bullying behavior instrument adaptation from Hastuti, Herien, and Djaswelma (2015) with the reliability of 0.902. Data analysis used in this study was descriptive statistical analyses and statistical analyses of Pearson correlation and linear regression tests. The data were collected using self-administered questionnaires guided by the researcher. The results showed that more than half of adolescents had perceptions of affective parenting. However, about 40 percent of adolescents have self-esteem in the low category. The most common type of bullying behavior adolescents is verbal bullying. The test results showed that parents with aggression and undifferentiated rejection are unfortunately related to the adolescents' bullying, and low adolescents' self-esteem is followed by bullying behavior. Gender (male adolescents) and low self-esteem had a significant effect on bullying behavior. Meanwhile, parental rejection had a significant positive effect on bullying behavior.
\end{abstract}

Keyword: adolescent, bullying, maternal acceptance-rejection, self-esteem

\section{Introduction}

Deviant behavior and problems that occur among adolescents today are quite diverse, for instance bullying behavior. The results of research conducted in 66 countries and regions from five continents indicated that bullying is very prevalent throughout the world, as many as 32 percents of early adolescents aged 13-15 years who were reported to have been bullied at least once in the last two months (Due \& Holstein, 2008). The results of the symposium conducted by UNICEF in 2016 and attended by 100,000 adolescents from 18 countries showed that two-thirds of the teenagers present were reportedly involved in bullying behavior. In Indonesia, bullying behavior also has widespread in school-age children and mostly occurs in educational environments. This study involved junior high school students because the problem of bullying was more often found in middle school age children. This funding is in line with Shaheen et al. 
(2018) and Huang et al. (2013) that younger adolescents are more involved in bullying behavior than older teens.

Furthermore, Survey of Child Welfare League Foundation (2007), there were around $60 \%$ of students in elementary school and junior high school that have been bullied. The Indonesian Child Protection Commission (2016) also showed 93 cases and then increased to 112 cases in 2016. Bullying behavior in adolescents in Indonesia is evident by the results of Sejiwa (2008) 66percent of junior high school students and 67.9 percent of high school students.

The problem of violent and bullying behavior is very vulnerable in large cities. Sejiwa's research (2008) shows that the bullying behavior of students at the junior high school level in sequence occurred in Yogyakarta (77.5\%), Jakarta $(61.1 \%)$ and Surabaya (59.8\%). The city of Bogor as one of the big cities as well as the capital city buffer also has a problem of reasonably high bullying behavior. The results of research conducted by Hastuti et al. (2013) showed that the asocial behavior of adolescents in Bogor City and Regency has a high probability of using drug, pornography, brawls, online gaming, and bullying. Besides, the City of Bogor is one of the cities with 40 percent of students involved in bullying behavior based on Junior Chamber International (2016) records.

Bullying in schools divided into two main categories, directly or indirectly. Some examples of direct bullying include encouraging, kicking, fighting and some including the use of weapons. Some examples of indirect bullying include teasing, mentioning names, exceptions, and rumors. At this time there have been many cases of cyberbullying through Internet means among school children. Eskisu (2014) states that bullying behavior will have a negative impact on physical, social, psychological, and risky conditions in the future.

Bullying behavior that occurs in adolescents in almost all corners of the world is also influenced by several factors including internal factors and external factors. The results of research conducted by Wang et al. (2012) found that adolescents involved in bullying behavior were caused by several factors such as demographic characteristics, family, school environment, and psychosocial adjustments. The mother as the primary caregiver of the child is expected to be a good role model. Care for mother's acceptance that is warm, caring and loving will form a good reception for children. The lack of warmth and acceptance given by the mother, the permissive attitude given by the mother, the use of physical punishment, and parenting patterns that are not in accordance with the child's temperament influence the bullying behavior (Olweus, 2003). Guindon's research (2009) found that internal factors in an individual that influence bullying behavior, one of which is self-esteem. Another factor that influences the occurrence of bullying behavior is the swift flow of information through media such as television and gadgets that are increasingly spreading among children and adolescents (Anwas, 2010).

This study aims to identify the characteristics of adolescents, family characteristics, maternal acceptance-rejection, self-esteem, and bullying behavior of junior high school students. This study also aims to analyze the relationship between maternal acceptance-rejection, and self-esteem with the bullying behavior of junior high school students. Furthermore, this study also aims to analyze the factors that influence the bullying behavior of junior high school students. 


\section{Methods}

The design used in this study is a cross-sectional study, namely research conducted at a particular time. This research was conducted in two junior high schools in West Bogor and South Bogor Subdistricts. The location of the study was selected purposively based on recommendations from the Bogor City Education Office. The consideration of choosing these two locations is because West Bogor Subdistrict is one of the sub-districts with a relatively dense population and a large number of schools, while South Bogor Subdistrict is a subdistrict with a dense population but the number of secondary schools is limited. An example in this study was 86 students whose in their eighth grade in two selected schools taken using simple random sampling technique and calculated using the Slovin formula $(\mathrm{e}=10 \%)$. Furthermore, five respondents were selected to be interviewed with the criteria of having high parenting problems and have experienced bullying behavior based on self-administered results in the research questionnaires.

The data that had been collected is primary data which is already tested its reliability and validity as well as secondary data obtained from the school. Primary data was obtained through self-administered using questionnaires guided by researchers. Characteristics of adolescents include age and sex. Family characteristics include maternal age, length of mother's education, type of mother's work, and family size.

The variables of parental acceptance-rejection are measured using the Parental Acceptance-Rejection (PAR) questionnaire adaptation from Rohner (1986) which is grouped into the dimensions of affection, aggression, neglect, and undifferentiated rejection with 60 statement items. The questionnaire uses 4 rating scales, namely $0=$ incorrect, $1=$ rarely true, $2=$ sometimes true, and $3=$ almost always true. The value of Cronbach's alpha questionnaire is 0.785 with 59 valid statements and one invalid statement. The variable self-esteem was measured using the Rosenberg Self Esteem Scale questionnaire developed by Rosenberg (1965) with 10 statement items divided into two categories, namely half of the items were positive expressions and the other half were negative expressions. The questionnaire uses 4 rating scales, namely $0=$ very inappropriate, $1=$ not appropriate, $2=$ appropriate, and $3=$ very appropriate. The value of Cronbach's alpha questionnaire is 0.773 with ten valid statements.Bullying behavior variables were measured using a questionnaire referring to Djaswelma, Hastuti, and Puspitawati (2015) with 25 number of statement items. The questionnaire uses 4 rating scales, namely $0=$ never, $1=$ rarely, $2=$ often, and $3=$ always. The value of Cronbach's alpha questionnaire is 0.902 with 25 valid statements.

The data collection process is carried out on the same day at each school. Respondents who were involved in the study were determined in advance using a simple random sampling technique. Respondents were collected in two separate classes with the same proportions. During the data collection process, the researcher explained how to fill out the questionnaire in detail to the respondents. After being explained, the researcher directed the respondents to fill in the questionnaires one by one until the last question. The results of the data scoring are summed to obtain a total score which is then transformed into an index. Furthermore, the index scores obtained are categorized into two, namely low and high with a low cut-off point ( $<$ index average) and high $(\geq$ index average). Data processing using Microsoft Office Excel software and data analysis was performed using the Statistical Package for Social Science (SPSS) program. Descriptive statistical analyses are used to analyze frequencies, averages, and 
standard deviations. Inference statistical analyses used is the Pearson correlation test to analyze the relationship between variables, and multiple linear regression tests to analyze the factors that influence bullying behavior.

\section{Findings}

\section{Adolescents' and Families' Characteristics}

The samples involved in this study were adolescents aged 13 to 15 years consisting of 41 males and 45 females. More than half of adolescents (56.9\%) were 14 years old. The most significant proportion of male adolescents were at the age of 14 years $(38.4 \%)$, while the female adolescents were at the age of 13 years $(31.4 \%)$. Distribution of maternal age is classified into three, namely early adulthood (18-40 years), middle adulthood (41-60 years), and advanced adult (>60 years) (Hurlock 1980). The results found that half of the adolescent mothers $(50.0 \%)$ were in the early adult age group (18-40 years) and middle-aged (41-60 years). The average mothers' educational level is 10.42 years in which categorized as good. Eight out of ten mothers do not work or as housewives, the rest (1.2\%) are workers. The size of the family is measured by the number of family members and categorized into three groups, namely small family (number of members $\leq$ four people), moderate family (number of 5-7 members), and extended family (number of members $\geq$ eight people) (BKKBN, 1998). More than half of teenagers $(55.8 \%)$ belong to the category of moderate family (5-7 people) with an average number of family members of 5 people.

\section{Maternal acceptance-rejection}

Parenting parents based on the dimensions of warmth according to Rohner (1986) are classified into two main categories, namely parenting acceptance and rejection. This study looks at how parental acceptance-rejection applied by mothers is based on teenage perceptions. The results showed that affection dimensions had the highest average of 71.9 (Table 1). The results of this study are in line with the research conducted by Volunteer (2014) that the average affection is the highest dimension. However, the average care for aggression, neglect, and undifferentiated rejection by mothers in this study were higher than previous studies. The Volunteer Research (2014) showed a lower mean score of 19.3 parenting aggression, 17.5 neglect care, and 13.1 undifferentiated rejection.

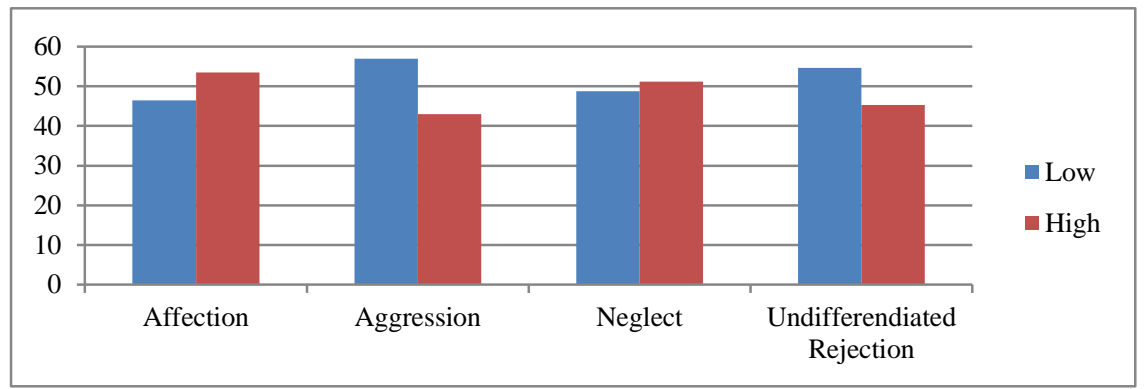

Figure 1 Adolescents categories based on parental acceptance-rejection

More than half of adolescents (53.5\%) considered that their mothers show warmth and affection. This can be seen from the perception of adolescents that mothers make adolescents proud when doing the right thing (93.0\%) and mothers try to make 
adolescents happy (94.2\%). In the dimension of care for aggression more than half of the adolescents $(57.0 \%)$ had a low perception. This happens because adolescents feel that mothers have never treated teenagers with harshness $(87.2 \%)$ and mothers have never hit them $(88.3 \%)$. In the dimension of neglect, more than half of the adolescents $(51.2 \%)$ have a high perception because adolescents feel that mothers ignore teenagers while not doing something that disturbs the mother $(46.6 \%)$ and the mother is too busy to be able to answer teen questions $(51.1 \%)$. In undifferentiated rejection, more than half of teenagers $(54.7 \%)$ had a low perception for adolescents feel it is not true if the mother does not love her too much $(87.3 \%)$ and is not right if the mother shows her that she is unwanted $(91.8 \%)$.

\section{Adolescents' Self Esteem}

Self-esteem in its development is formed as the results of an individual's interaction with the environment and for a number of awards, acceptance, and understanding of others towards him or her. Rosenberg (1965) divides self-esteem into two components globally, namely positive and negative attitudes. The results showed that 43.0 percent of adolescents had low self-esteem, and more than half of adolescents $(57.0 \%)$ had high categorized self-esteem with an average level of self-esteem 65.8. There are plenty adolescents (43\%) with low categorized self-esteem (below 65.8) indicating that teenagers in junior high schools experiencing self-confidence problems.

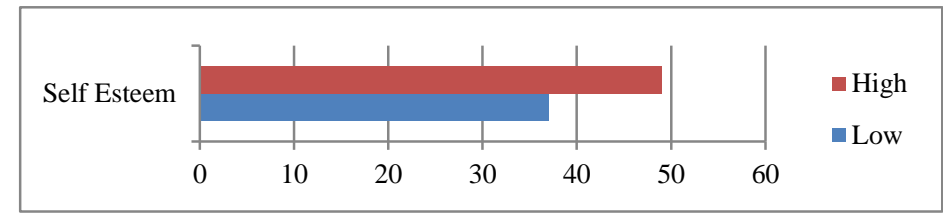

Figure 2 Adolescents categories based on self-esteem

The results showed that almost all adolescents $(93.0 \%)$ were positive about themselves, able to do things as well as others $(87.2 \%)$ and feel proud of themselves (86.0\%). However, in this study, there are still adolescents who have low self-esteem. This happens because adolescents feel that other people do not appreciate it (48.8\%), see themselves as people who failed (40.7\%), and feel worthless (27.9\%)

Table 1 The distribution of adolescents is based on maternal acceptance-rejection and self-esteem

\begin{tabular}{lcccccc}
\hline \multirow{2}{*}{ Variables } & \multicolumn{2}{c}{ Low } & \multicolumn{2}{c}{ High } & Min-max & Average \pm \\
\cline { 2 - 4 } & $\mathrm{n}$ & $\%$ & $\mathrm{n}$ & $\%$ & & SD \\
\hline Parental Acceptance-Rejection & & & & & & \\
$\quad$ Affection & 40 & 46,5 & 46 & 53,5 & $18,3-95,0$ & $71,9 \pm 15,1$ \\
$\quad$ Aggression & $\mathbf{4 9}$ & $\mathbf{5 7 , 0}$ & 37 & 43,0 & $2,2-91,1$ & $32,5 \pm 17,9$ \\
$\quad$ Neglect & 42 & 48,8 & 44 & 51,2 & $0,0-68,9$ & $25,9 \pm 13,5$ \\
$\quad$ Undifferentiated Rejection & 47 & 54,7 & 39 & 45,3 & $6,7-83,3$ & $32,9 \pm 16,4$ \\
Self-esteem & 37 & 43,0 & 49 & 57,9 & $33,3-93,3$ & $65,8 \pm 13,3$ \\
\hline
\end{tabular}

\section{Adolescents' Bullying Behavior}

Bullying behavior in this study is grouped into physical, verbal, and indirect bullying. The results showed that the type of bullying behavior that is more often 
carried out by adolescents is verbal bullying with the highest average of 32.6, then followed by indirect bullying and physical bullying (Table 2).

Table 2 Distribution of adolescents based on bullying behavior

\begin{tabular}{lcc}
\hline \multicolumn{1}{c}{ Variables } & Min-max & Average \pm SD \\
\hline Physical Bullying & $0,0-62,5$ & $20,2 \pm 15,1$ \\
Verbal Bullying & $0,0-66,7$ & $32,6 \pm 16,2$ \\
Indirect Bullying & $0,0-80,0$ & $24,7 \pm 15,5$ \\
\hline
\end{tabular}

The results showed that five out of ten adolescents (52.3\%) were involved in high-category bullying behavior. Verbal bullying that is most often done by adolescents in this study is to laugh at friends who are being ridiculed $(94.1 \%)$, ridicule friends using their parents' names $(83.7 \%)$, give rude nicknames to certain friends $(67.4 \%)$, and quip certain students with curse words $(79.0 \%)$. Physical bullying behavior that is mostly done by adolescents is deliberately hiding friends' belongings (65.1\%) and joining friends while fighting (55.8\%). Meanwhile, indirect bullying that is mostly done by adolescents is looking at individual students cynically when they meet (76.7\%) and participate away from friends who are not liked by their close friends $(74.4 \%)$.

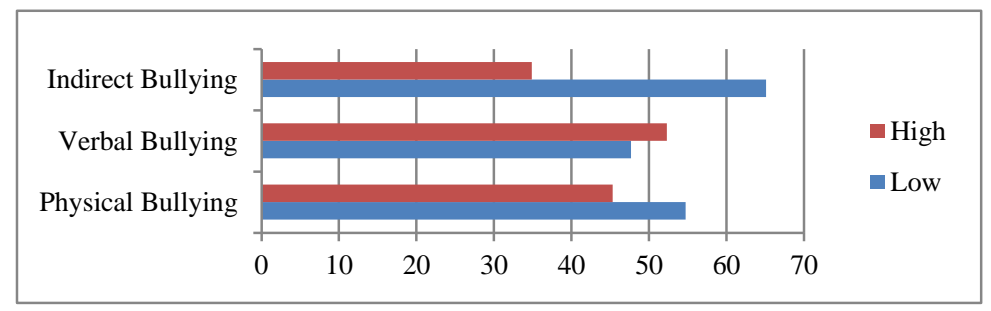

Figure 3 Adolescent categories based on bullying behavior

Based on the distribution of adolescent answers to the questionnaire, it can be seen that all adolescents have committed bullying despite different intensities. Verbal bullying is most common because adolescents consider it to be something natural. A study based on three national surveys in the USA reported that the most common forms of bullying were verbal insults such as name calling (UNESCO, 2017).

\section{The Relationship Between Characteristics and Maternal Acceptance-Rejection}

The results showed that maternal education duration had a significant positive relationship with affection parenting $(\mathrm{r}=0.213 ; \mathrm{p}<0.05)$ and a significant negative relationship with neglection $(r=0.256 ; \mathrm{p}<0.05)$. This shows that the longer the mother's education, the higher the affection parenting is applied and the lower the neglection. Meanwhile, larger families had a significant negative relationship with affection parenting $(\mathrm{r}=0.251 ; \mathrm{p}<0.05)$ and a significant positive relationship with neglection $(\mathrm{r}=0.240 ; \mathrm{p}<0.05)$. This shows that the greater the family, the lower affection parenting and the higher neglect parenting applied by the mother to their child (Table 3). 
Table 3 Correlation coefficients between characteristics with maternal acceptancerejection

\begin{tabular}{lcccc}
\hline \multirow{2}{*}{ Variables } & \multicolumn{4}{c}{ Correlation coefficients } \\
\cline { 2 - 5 } & Affection & Aggression & Neglect & $\begin{array}{c}\text { Undifferentiated } \\
\text { Rejection }\end{array}$ \\
\hline Adolescents Gender & 0.90 & -0.037 & -0.036 & 0.106 \\
Mother's Age (year) & 0.095 & -0.039 & -0.003 & -0.020 \\
Maternal education & $\mathbf{0 . 2 1 3 *}_{\text {Family size }}$ & 0.019 & $\mathbf{- 0 . 2 5 6 *}$ & -0.193 \\
\hline Desil & $\mathbf{- 0 . 2 5 1}^{*}$ & -0.059 & $\mathbf{0 . 2 4 0}$ & 0.077 \\
\hline
\end{tabular}

Description: $* *=$ significant at $\mathrm{p}<0.01, *$ significant at $\mathrm{p}<0.05$

\section{Relationship Between Characteristics with Adolescents' Self Esteem}

The results showed that the sex of adolescents had a significant negative relationship with self-esteem $(r=0.326 ; \mathrm{p}<0.01)$. This shows that self-esteem for male adolescents is higher than for female adolescents (Table 4). This is in line with Coopersmith's (1965) statement that women have lower self-esteem than men because they feel less capable and feel they must be protected.

Table 4 Correlation coefficients between characteristics with self-esteem

\begin{tabular}{lc}
\hline \multirow{2}{*}{ Variables } & Correlation coefficients \\
\cline { 2 - 3 } Adolescents Gender $(0=$ male, $1=$ female $)$ & $\mathbf{- 0 . 3 2 6} * *$ \\
\hline Description: $* *=$ significant at $\mathrm{p}<0.01, *=$ significant at $\mathrm{p}<0.05$ &
\end{tabular}

\section{Correlation}

The results showed affection care had a significant positive relationship with self esteem $(r=0.354 ; p<0.01)$ meaning that the higher the affection parenting applied by the mother, the higher the self-esteem possessed by adolescents. Meanwhile, parenting aggression had a significant negative relationship with self-esteem $(r=0.230 ; p<0.05)$ meaning that the higher parenting aggression applied by the mother, the lower the teenage self-esteem. Parenting neglect had a significant negative relationship with selfesteem $(\mathrm{r}=0.416 ; \mathrm{p}<0.01)$ meaning that higher parenting care applied by the mother, the lower the adolescents' self-esteem. Also, it was also found that there was a significant negative relationship between undifferentiated rejection with self-esteem $(r=$ $0.398 ; \mathrm{p}<0.01$ ), meaning that the higher parenting feelings applied by the mother, the lower the self-esteem possessed by adolescents (Table 5).

Table 5 Correlation coefficient between acceptance-rejection parenting with self-esteem

\begin{tabular}{lc}
\hline \multirow{2}{*}{ Variables } & Correlation coefficient \\
\cline { 2 - 2 } Affection & Self esteem \\
Aggression & $\mathbf{0 , 3 5 4} 4^{* * *}$ \\
Neglect & $\mathbf{- 0 , 2 3 0}$ \\
Undifferentiated rejection & $\mathbf{- 0 , 4 1 6}$ (1* $^{* *}$ \\
\hline
\end{tabular}

Description: $* *=$ significant at $\mathrm{p}<0.01, *=$ significant at $\mathrm{p}<0.05$ 


\section{Maternal Acceptance-Rejection and Self Esteem with Bullying Behavior}

The results showed that there was a significant positive relationship between parenting aggression with bullying behavior $(r=0.258$; $p<0.01)$ meaning that the higher parenting aggression applied by the mother, the higher the bullying behavior carried out by the adolescents. Furthermore, there was a significant positive relationship between undifferentiated rejection parenting with bullying behavior $(r=0.307 ; \mathrm{p}<0.01)$ meaning that the higher parenting undifferentiated rejection is applied by the mother, the higher the teen bullying behavior will be. Meanwhile, there was a significant negative relationship between self-esteem and bullying behavior $(r=0.240 ; p<0.05)$. This shows that the higher the self-esteem possessed by adolescents, the lower the involvement of adolescents in bullying behavior (Table 6).

Table 6 Correlation coefficients between maternal acceptance-rejection and self-esteem with bullying behavior

\begin{tabular}{lc}
\hline \multirow{2}{*}{ Variables } & Coefficient correlations \\
\hline Affection & Bullying behavior \\
Aggression & $-0,163$ \\
Neglect & $\mathbf{0 , 2 5 8 * *}$ \\
Undifferentiated Rejection & 0,190 \\
Self esteem & $\mathbf{0 , 3 0 7 * *}$ \\
\hline
\end{tabular}

Description: $* *=$ significant at $\mathrm{p}<0.01, *=$ significant at $\mathrm{p}<0.05$

\section{Predictors of Bullying Behavior}

Table 7 shows the predictors of adolescents' bullying behavior. This model can explain the factors that influence bullying behavior by 15.7 percent (Adjusted R Square $=0.157)$, while the rest is influenced by other variables not examined. Based on previous research conducted by Karina (2012); Wang et al. 2012; and Arifinda (2015) found that bullying behavior carried out by a person can also be influenced by environmental factors such as access to television media, school environment, and the influence of peer groups.

Table 7 also shows that gender had a significant adverse effect on adolescent's bullying behavior. This shows that male adolescents tend to increase their bullying behavior score by 9,345 points $(B=-9,435 ; p<0.01)$. Care for mother's rejection had a significant negative effect on adolescent's bullying behavior. This shows that every increase in a score of parenting rejection increases adolescent bullying behavior by 0.208 points $(\mathrm{B}=0.208 ; \mathrm{p}<0.1)$. Self-esteem had a significant negative effect on adolescents' bullying behavior. This shows that every increase in one self-esteem score will reduce adolescents' bullying behavior by 0.296 points $(B=-0.296 ; p<0.05)$.

Table 7 Regression coefficients between adolescent characteristics, family characteristics, maternal acceptance-rejection, and self-esteem towards bullying behavior of junior high school students

\begin{tabular}{lccc}
\hline \multirow{2}{*}{ Variables } & $\begin{array}{c}\text { Non standardized } \\
\text { coefficient }\end{array}$ & $\begin{array}{c}\text { Standardized } \\
\text { coefficient }\end{array}$ & Sig \\
\cline { 2 - 4 } & $\mathrm{B}$ & Beta & \\
\hline Constants & 51,144 & & 0,005 \\
Gender $(0=$ male, $1=$ female $)$ & $-9,435$ & $-0,365$ & $\mathbf{0 , 0 0 1} * * *$ \\
\hline
\end{tabular}




\begin{tabular}{lccc}
\hline \multirow{2}{*}{ Variables } & $\begin{array}{c}\text { Non standardized } \\
\text { coefficient }\end{array}$ & $\begin{array}{c}\text { Standardized } \\
\text { coefficient }\end{array}$ & Sig \\
\cline { 2 - 4 } & $\mathrm{B}$ & Beta \\
\hline Mother's Age (years) & 0,055 & 0,022 & 0,833 \\
Maternal education (years) & $-0,412$ & $-0,105$ & 0,307 \\
Family size (people) & $-0,468$ & 0,944 & 0,622 \\
Mother's affection parenting (score) & 0,088 & 0,102 & 0,427 \\
Mother's rejection parenting (score) & 0,208 & 0,217 & $\mathbf{0 , 0 7 8}$ \\
Self Esteem (score) & $-0,296$ & $-0,303$ & $\mathbf{0 , 0 1 4}$ \\
\hline F & \multicolumn{3}{c}{2,676} \\
R Square & \multicolumn{3}{c}{0,226} \\
Adjusted R Square & \multicolumn{3}{c}{0,157} \\
Sig & \multicolumn{3}{c}{$\mathbf{0 , 0 0 4 * * *}$} \\
\hline
\end{tabular}

Description: $* * *=$ significant at $\mathrm{p}<0.01, * *=$ significant at $\mathrm{p}<0.05, *=$ significant at $\mathrm{p}<0.1$

\section{Discussion}

The results showed that the type of bullying behavior that is more often carried out by adolescents is verbal bullying such as laughing at a friend who is being ridiculed, ridiculing a friend using a parent's name, and giving a rude nickname to other students. This is in line with research conducted by Piskin (2010) and Karina (2012) that the form of bullying that occurs most often in adolescents is verbal bullying, one of which gives a rude nickname to other students. Another study conducted by Tsaousis (2016) found that the type of bullying that is most often carried out by adolescents is verbal bullying, especially not-so-good name-calling and spreading rumors or gossip. Verbal bullying is most common because most teenagers feel that it is natural and sometimes adolescents do not realize that the words they say have hurt the feelings of others.

More than half of the adolescents in this study had a perception of affection parenting in the high category. High maternal affection care is demonstrated by the behavior of affection and warmth in physical and verbal forms. The results of this study also showed that more than half of teenagers had a perception of parenting neglect in the high category. Based on the results of in-depth interviews, this is suspected because mothers often ignore and choose favoritism so that teenagers feel that they do not get the attention of their mother. Some teenagers also said that mothers were too busy with their affairs even though most mothers in this study did not work or as housewives. In care, mothers should be able to share feelings, meet children's needs, and show affection (Ogelman, 2015).

More than half of adolescents had a high level of self-esteem. However, the results of the study found that 4 out of 10 adolescents still had low self-esteem. Adolescents with low self-esteem have characters that are not consistent in responding to something. They consider themselves are not valuable and important, do not have the ability as well as other individuals at their age, and feel not valued as someone's (Coopersmith, 1967). The in-depth interviews examined adolescents who have low selfesteem mostly tend to feel others do not respect themselves. According to Rosen et al. (1982) in Triantoro (2015), someone with low self-esteem has a higher level of fear when facing a threat or problem and considers himself a person who does not have adequate skills to deal with problems.

Research shows that there is a significant positive relationship between parenting aggression and undifferentiated rejection of adolescent bullying behavior. This finding is in line with Atik and Guneri (2013) that adolescents who are involved in 
bullying behavior perceive that their parents lack love, involvement, and responsibility. Other research conducted by Wright (2016) shows that victims and perpetrators of bullying are associated with the warmth of parents in poor parenting practices. Children who get a rejection from parents significantly show more hostile and aggressive traits than children who are accepted (Rohner, 1986). This is the reason why children who feel rejected their presence will increase their involvement in bullying behavior than children who feel themselves accepted.

The results also showed that self-esteem was significantly negative with bullying behavior. Adolescents who have high self-esteem are increasingly involved in bullying behavior, and vice versa. This is supported by research conducted by Cook et al. (2010) that adolescents with low self-esteem will tend to be involved in bullying behavior either as victims or as perpetrators. Adolescents who oppress others use bullying as a means to cover their low self-esteem (Patchin \& Hinduja, 2010).

Parenting of acceptance-rejection applied by the mother also shapes the selfesteem that teenagers have. This is in line with the results of Aslan's (2011) study that the more parental acceptance obtained by adolescents, the higher the self-esteem possessed by adolescents. High self-esteem that is owned by adolescents will also increase their self-confidence and a sense of security. Meanwhile, when mothers are aggressive, ignorant, and do not show their affection for adolescents, adolescents will feel that they are not needed, not accepted, and do not have something to be proud of, thus low self-esteem is formed. Another study conducted by Cournoyer et al. (2005) found that the parenting style of aggression, neglection, and feelings of distress given by mothers relate to adolescents' negative feeling and incapability of doing something.

The results showed a significant positive relationship between the duration of maternal education and affection care and a significant negative relationship between maternal education and parenting. This is in line with the research conducted by Riska and Krisnatuti (2016) that a mother who has a higher education can apply good affection care. A mother who has a higher education has a better understanding of parenting thus she could perform in daily life. The size of the family in this study is negatively related to affection care, and it is positively related to parental care. This is in line with the research of Rahayu (2017) that the higher the family will cause mothers to be more negligent towards children.

The results of the multiple regression analysis tests showed that gender, rejection, and self-esteem were the factors in influencing bullying behavior. This is in line with research conducted by Cook et al. (2010) that family is one of the factors predicted as the cause of a child involved in bullying behavior. This study found that there are still some mothers in their daily life using harsh words to their teenagers, are too busy with their affairs, choose love, and commit acts of physical violence such as hitting. Children who are accustomed to getting a rejection from their parents will feel less secure, lose shelter, so they tend to withdraw and do not have good social relations with their peers. However, the opposite can also happen that when a child is rejected the child can act aggressively even against his parents. Based on the results of in-depth interviews, adolescents who are accustomed to getting abusive treatment from mothers verbally or physically often vent their resentment and anger at their friends at school. This is in line with Albert Bandura's Social Learning Theory (1965) that violent behavior by children is mostly a behavior learned from experience, through direct observation of people who behave violently, then imitating it. 
Adolescent self-esteem in this study also influences the occurrence of bullying behavior. This finding is in line with the research of Fitria and Auli (2016) who said that in addition to the family environment, bullying behavior experienced by students is also influenced by their self-esteem. The results of other studies conducted by Tsaousis (2016) say that one of the factors that influence bullying behavior is the self-esteem that a person has. Self-esteem plays a vital role in the development of children's behavior which will illustrate how a child establishes relationships with other people and shows how accepted they are by others. Someone who feels that he or she is accepted can establish good social relations, thus reducing his chances of being involved in bullying behavior.

Gender in this study is one of the factors that influence adolescent bullying behavior. This is in line with several studies that men have a higher level of involvement in bullying behavior than women (Atik \& Guneri, 2013; Carlerby et al., 2013). Men are defined as someone who is accustomed to taking risky actions, likes to fight, and is involved in a group or 'gang.' A study conducted in Australia shows that men who receive bullying from others tend to feel angry and fight, while women say they feel sad and prefer to be silent (Owens, 2005).

This study has limitations, that is measurement only sees the child's perception of the acceptance-rejection parenting style applied by the mother, while father also has a significant role in parenting as an effort to prevent the development of deviant behavior of adolescents.

\section{Conclusions And Recommendation}

\section{Conclusion}

The results showed that all adolescents in the study had been involved in bullying behavior. The level of adolescent verbal bullying behavior is high, while the level of physical and indirect bullying behavior is still relatively low. The type of verbal bullying behavior that is most often done by teenagers is to laugh at friends who are being ridiculed, ridicule friends using parents' names, give rude nicknames to certain students, and tease certain students with curse words. The results also show that more than half of adolescents have perceptions of affection parenting, but there are still teenagers who perceive parenting styles of neglect, neglect, and undifferentiated rejection. The level of high self-esteem has been achieved by more than half of the examples, but it is seen that the average adolescent self-esteem example as a whole is still relatively low. Relationship analysis shows that high affection care will increase adolescent self-esteem. Meanwhile, parenting aggression, neglect, and undifferentiated rejection will reduce adolescent self-esteem. The results of the relationship test also show that parenting aggression and high undifferentiated rejection will increase adolescent bullying behavior. Meanwhile, high self-esteem that is owned by adolescents will reduce teen bullying behavior. The results of the effect test showed that the care of maternal rejection, self-esteem, and male gender were factors that influence adolescent bullying behavior.

\section{Recommendation}

Based on the results of the study, the school is expected to be able to improve counseling guidance activities into a forum for students to be able to tell problems so that bullying behavior can be prevented. Besides that, socialization to each class can be 
done by the BK teacher so that each child is improved self-esteem, and the teacher gives socialization to students not to bullying because it will have a negative impact on students and the school environment. The school can also provide information and socialize good parenting to parents through meetings. This is considering that adolescents who feel welcome their presence will have good self-esteem so that they can establish good relationships with others and reduce their involvement in bullying behavior. The Education Agency is expected to be able to carry out educational activities related to the dangers and impacts of bullying behavior on students through collaboration with the school. The Education Office can also develop character-based learning systems in specific subjects to prevent bullying behavior in schools. For further research can be measured by looking at the role of fathers in parenting practices. Furthermore, it can be studied how peer influences the development of adolescent bullying behavior. According to Erickson's psychosocial theory that adolescents are at the stage of identity vs. role confusion and interact more with their peers so that the influence of peer environment is quite considerable in the development of adolescent behavior. Parents need to understand family roles are essential for children's development, so it is necessary to apply positive care for children in life, such as increasing activities with children, inviting children to talk about their activities openly, establishing good relationships with schools to control children's behavior in school.

\section{References}

Anwas, O.M. (2010). Televisi mendidik karakter bangsa: Harapan dan tantangan. Jurnal Pendidikan dan Kebudayaan. 16(3), 256-266.

Arifinda, N.A. (2015). Pengaruh akses media televisi dan peniruan muatan kekerasan terhadap perilaku bullying siswa sekolah dasar [skripsi]. Bogor (ID): Sekolah Pascasarjana IPB.

Aslan, S. (2011)._The analysis of the relationship between school bullying perceived parenting styles and self-esteem in adolescents. Journal Procedia - Social and Behavioral Sciences. 30, 1798-1800.

Atik, G., Gurneri, O.Y. (2013). Bullying and victimization: Predictive role of individual, parental, and academic factors. School Psychology International. 34(6): 658-673.

Bandura, A. (1965). Influence of models' reinforcement contingencies on the acquisition of imitative responses. Journal of Personality and Social Psychology. 1(6).

[BKKBN]. Badan Koordinasi Keluarga Berencana Nasional. 1998. Data Besar Keluarga [internet]. [Diunduh pada 2018 February 2]. Tersedia pada http://bkkbn.go.id

Carlerby, H., Viitasara, E., Knuttson, A., Gadin, K.G. (2013). How bullying involvement is associated with the distribution of parental background and with subjective health complaints among Swedish boys and girls. Social Indicators Research. 111(3): 775-783.

Cook, C.R., Williams, K.R., Guerra, N. (2010). Predictors of bullying and victimization in childhood and adolescence: A meta-analytic investigation. School Psychology Quarterly. 25, 65-83.

Coopersmith, S. (1967). The Antecedents of Self-Esteem. San Francisco: W.H. Freeman. 
Cournoyer, D.E., Sethi, R., Cordero, A. (2005). Perceptions of parental acceptance rejection and self concept among university students. Pro Quest Sociology. 33 (3), 335

Djaswelma. (2015). Gaya pengasuhan ibu dan perilaku bullying remaja pada keluarga bercerai di kota bogor. [tesis]. Bogor (ID): Sekolah Pascasarjana IPB.

Due, P \& Holstein, B.E. (2008). Bullying victimization among 13 to 15 -year-old school children: results from two comparative studies in 66 countries and regions. International Journal Adolescent Medical Health. 20(2): 209-222.

Eskisu, M. (2014). The relationship between Bullying, family functions and perceived social support among high school students. Journal Procedia Social and Behavioral Sciences. 159, 492-496.

Fitria., Auli, R. (2016). Faktor-faktor yang berhubungan dengan perilaku bullying. Idea Nursing Journal. 7(8), 9-17.

Guindon, M.H. (2009). What is Self-esteem? Di dalam: Guindon MH, editor. Selfesteem Across the Lifespan. New York: Rotledge,3-24.

Hastuti, D., Agung, S.S., Alfiasari. (2013). Kajian karakteristik remaja desa-kota, sekolah, serta keluarga untuk mengatasi perilaku antisosial remaja SMK di Kota dan Kabupaten Bogor. Prosiding Seminar Hasil-Hasil PPM IPB II, hlm 653-667.

Karina. (2012). Perilaku bullying dan karakter remaja serta kaitannya dengan karakteristik keluarga dan peer group. Jurnal Ilmu Keluarga dan Konsumen. 6(1), 20-29.

[KPAI] Komisi Perlindungan Anak Indonesia. (2016). Kasus Pengaduan Anak Berdasarkan Klaster Perlindungan Anak. Diambil dari: http://kpai.go.id/berita/kpai-kasus-pengaduan-anak-berdasarkan-klasterperlindungan-anak/.

Ogelman, H.G., (2015). Predictor effect of parental acceptance-rejection levels on the resilience of preschool children. Journal Prosedia-Social and Behavioral Sciences. 174, 622-628.

Olweus, D. (2003). Bullying at School: Long Term Outcomes for The Victims And An Effective School-Based Intervention Programs. In: L.R Huesmann (Ed) Aggressive Behavior: Currents perspectives. New York. Plenum Pers.

Owens, L. (2005). Sex and age differences in victimization and conflict resolution among adolescents in a South Australian school. Aggressive Behaviour. 31(1).

Patchin, J.W., Hinduja, S. (2010). Cyberbullying and self-esteem. Journal of School Health. 80(2): 614-621.

Piskin, M. (2010). Examination of peer bullying among primary and middle school children in Ankara. Egitim ve Bilim. 35(156): 175-189.

Rahayu, N.D. (2017). Pengaruh pengasuhan penerimaan penolakan dan kelekatan ibuanak terhadap karakter disiplin anak usia prasekolah [skripsi]. Bogor (ID): Institut Pertanian Bogor.

Riska, H.A., Krisnatuti, D. (2016). Self esteem remaja perempuan dan kaitannya dengan pengasuhan penerimaan-penolakan ibu dan interaksi saudara kandung. Jurnal Ilmu Keluarga dan Konsumen. 10(1): 24-35.

Rohner, R.P. (1986). The Warmth Dimension Of Parenting: The Parental Acception Rejection Theory. Beverly Hills, California, US: Sage Publication Santrock, J. W. (2003). Adolescence: ed keenam. Jakarta (ID): Erlangga. 
Rosenberg, M. (1965). Society and The Adolescent Self-Image. Princeton, NJ: Princeton University Press.

[Sejiwa] Semai Jiwa Amini. (2008). Penelitian Menganai Kekerasan di Sekolah.

Triantoro, S. (2015). Are daily spiritual experiences, self-esteem, and family harmony predictors of cyberbullying among high school student?. International Journal of Research Studies in Psychology. 4(3): 23-33.

Tsaousis, I. (2016). The relationship of self-esteem to bullying perpetration and peer victimization among schoolchildren and adolescents: A meta-analytic review. Aggression and Violent Behavior.

UNESCO. (2017). School Violence and Bullying: Global Status Report. Presented at the International Symposium on School Violence and Bullying: From Evidence to Action, Seoul, Republic of Korea, 17 - 19 January 2017.

UNICEF. (2016). Special Representative of the Secretary-General on Violence against Children. Ending the torment: Tackling bullying from the schoolyard to cyberspace.

Voluntir, F. (2014). Pengasuhan penerimaan-penolakan dan lingkungan pengasuhan pada kelarga dengan anak remaja di area suburban [skripsi]. Bogor (ID): Institut Pertanian Bogor.

Wang, H., Zou, X., Lu, C., Wu, J., Deng, X., Hong, L., Gao, X., He, Y. (2012). Adolescent bullying involvement and psychosocial aspects of family and school life: a cross-sectional study from Guangdong province in China. Journal Plos One. 7(7), 1-10.

Wright, M.F. (2016). The roles of bullying involvement and parental warmth in nonsuicidal self-harm and suicidal ideation among adolescents from a residential program. Journal of criminal psychology. 6(4): 202-213. 